\title{
Phytotherapeutic approaches to treatment and prophylaxis in pediatric practice
}

\author{
Valentina Petkova ${ }^{1}$, Bozhidarka Hadzhieva $^{2}$, Paraskev Nedialkov ${ }^{1}$ \\ 1 Faculty of Pharmacy, Medical University - Sofia, Sofia, Bulgaria \\ 2 Medical University - Plovdiv, Plovdiv, Bulgaria \\ Corresponding author: Valentina Petkova (vpetkova@pharmfac.mu-sofia.bg)
}

Received 4 July 2019 • Accepted 18 September 2019 • Published 7 November 2019

Citation: Petkova V, Hadzhieva B, Nedialkov P (2019) Phytotherapeutic approaches to treatment and prophylaxis in pediatric practice. Pharmacia 66(3): 115-119. https://doi.org/10.3897/pharmacia.66.e37954

\begin{abstract}
Medicinal plants, their extracts and herbal medicinal products occupy a growing share of medicines in the pharmacy worldwide.

Historically, the first medicines were products of plants, as well as some of the most important medicines still in use today. With the development of phytochemistry, as part of the pharmaceutical science, great progress has been made in the isolation and in determining the value of a number of biologically active substances (BAS).

Many plants have yielded pure substances (or natural products) that are applied in modern medical practice. Other compounds are potentially useful or have toxic effects.

Traditional medicine incorporating many herbal medicines remains an important (and in some cases, the only) form of treatment in some countries, with increasing use in medical practice.

On the other hand, the fact that in pediatric patients there is a limitation, mainly moral and ethical, of the number of medications to be administered due to the difficulty of conducting clinical trials in children, stimulates the use of herbal medicines of proven quality, effectiveness and safety among this group of patients.
\end{abstract}

\section{Keywords}

phytotherapeutic, alternative medicines, pediatric, medicinal plants

\section{Introduction}

Phytotherapy is the use of herbal remedies for the treatment and prophylaxis of diseases. Phytotherapy is a scientifically proven medical practice and thus distinguishes itself from other, more traditional approaches, such as herbal treatment which relies on empirical assessment of medicinal plants and which is often related to traditional knowledge.
(Gupta 2016) Phytotherapy is a part of pharmacology as a scientifically proven prophylaxis and treatment with phyto products derived from medicinal plants or parts thereof.

French physician Henri Leclerc (1870-1955) transformed ordinary empiricism into clinical studies. He first used the term "phytotherapy" in 1913 and published var- 
ious issues of "Précis de phytotherapie" (Guidebook in phytotherapy), the first in 1922. As a result of the clinical trials, he introduced a large number of medicinal plants in the therapy (Menin 2012).

Another definition of phytotherapy is given by Professor H. E. Bock: "Herbal medicines are those using whole plants or are isolated from plants" (Weiss and Fintelmann 2000).

Phytotherapeutic preparations or "phytomedicines" are standardized plant products consisting of complex mixtures of one or more plants, which are used in most countries for the treatment of various diseases. According to the WHO definition, herbal medicines contain as active ingredients plant parts or plant materials in raw or processed state plus some excipients, i.e. solvents, diluents or preservatives (Calixto 2000).

\section{Materials and methods}

In preparing this article, we conducted a study in the MEDLINE database (available via PubMed), Cochrane Library and Google Scholar. We used the terms "phytotherapy" and/or "alternative medicine" in relation to "medicinal plants" and "pediatric patients". The survey covers post-2000 publications. Articles, published in English, were reviewed and, in cases where a given article was not available in full text, we reviewed the summary. The texts in the articles included randomized controlled trials (RCTs), prospective/retrospective studies, and reports involving alternative treatment, medicinal plants in the context of therapy the pediatric patients.

\section{Results}

In the development of pediatric dosage forms it should be taken into account that children differ from adults in many aspects of pharmacotherapy, including medication, drug toxicity and taste preferences. To confirm this is the well-known fact that "the child's organism is not a diminutive copy of the adult."

The authorization and manufacture of pediatric products is documented in a Regulation of the European Parliament and of the Council of the European Union (No 1901/2006), which discusses in detail the issues concerning the conduct of clinical trials in children (EU Parliament 2006).

The purpose of this Regulation is to facilitate the development and accessibility of medicinal products intended for use by children to ensure that the medicinal products used by the former have undergone high quality ethical research and have been approved for use in children, and to improve the available information on the application of medicinal products in different groups of children. These objectives should be achieved without the need for children to undergo unnecessary clinical trials and without delaying the approval of medicinal products for the population of other age groups (EU Parliament 2006).
In recent years, more and more parents have been considering the use of herbal medicines for their children for health prophylaxis and for the treatment of latter illnesses. The increased use of herbal medicines and medicinal herbs corresponds to their wide availability in pharmacies, drugstores and other sources.

A study found that American families whose children had chronic illnesses such as autism, cystic fibrosis, rheumatoid arthritis, or asthma were highly likely to use herbal remedies as part of their treatment regimen (Woolf 2013).

Many pediatricians have begun integrating the use of complementary/alternative medical therapies in conjunction with conventional health care (Cohen et al. 2005, Cohen and Kemper 2005, Zuzak et al. 2013).

The results of the studies indicate that pediatricians should be aware of all potential therapies and not just the conventional medicine methods, as parents increasingly use alternative therapies without informing doctors. The pediatrician can best advise the family by thoroughly asking parents about all the remedies the family uses to help the child with safe, effective and age-appropriate methods (Kemper and O'Connor 2004, Prussing et al. 2004, Kemper et al. 2008).

Studies have shown that the use of complementary and alternative medical therapies in pediatric practice is increasing. These therapies are common, especially for children with chronic illnesses (McCann and Newell 2005, Jean and Cyr 2007).

Most pediatric patients who use complement therapy also take conventional medicines. Parents point out the following reasons why they use conventional therapies and methods: they consider them effective, they also fear the adverse effects of conventional medicines, and they point out the need for personal attention (Kemper et al. 2008).

\section{Phytotherapeutic approaches in pediatric practice for treatment and prevention}

\section{Febrile conditions, colds, flu}

Cold is an acute localized viral infection of the upper respiratory tract including the nose, sinuses, pharynx and larynx. The virus spreads through contact with hands with secretions from an infected person (directly or indirectly), or by air from secretions and viruses(Heikkinen and Järvinen 2003).

Cold is one of the most common diseases in the world. Adults may suffer from a cold of 2 to 5 times a year, whereas in children this number is 7 to 10 times. Because of the high prevalence rate, especially among children, common cold is a prerequisite for significant economic and social difficulties. Symptoms of common cold in children typically reach a peak shortly after the onset of the disease. The duration of symptoms is from 7 to 10 days, and may vary from 2 to 14 days (Troullos et al. 2014).

Several plant substances from different healing plants against flu and cold have been used in Europe: linden flowers (Tilia spp. L.); black elderberries berries and flowers (Sambucus nigra L.); echinacea stems and roots 
(Echinacea purpurea (L.) Moench); rosehip (Rosa canina L.); berries (Ribes nigrum L.), sea buckthorn (Hippophae rhamnoides L.) lemon juice and others.

Some studies conducted in Germany, examining patterns of use of herbal medicinal products, also indicated that most of the herbal medicinal products are used to treat cough and cold, followed by herbal therapy for intestinal disorders (Salvatore et al. 2012).

Other studies conducted in Germany among pediatric patients aged 0 to 17 found that herbal medicines are mainly used to treat coughs and colds among children. The study also found that a large proportion of herbal medicinal products are prescribed by doctors (Du et al. 2014).

Other medicinal plants or their phytoproducts that can be successfully applied in fever and influenza conditions are, for example: Icelandic moss (Cetraria islandica (L) Ach.); stems and primrose roots (Primula veris L.), ribwort plantain leaves (Plantago lanceolata L.); stems of common and wild thyme (Thymus vulgaris L., Thymus serpyllum L.); ivy leaves (Hedera helix L.); leaf colts (Tussilago farfara L.); stems of pot marjoram (Origanum vulgare L.); white mustard bark (Salix alba L.) and others. (Table 1).

\section{Diseases of the gastrointestinal tract}

Herbal medicines can be administered as a non-specific supplement to restore physiological functions but also in the treatment of specific conditions such as: functional disorders - dyspepsia, gastro-esophageal reflux, irritable bowel syndrome; inflammatory conditions of the upper tract - aphthous ulcers, oesophagitis, gastritis; chronic gastrointestinal infections and dysbiosis; constipation. (Borah et al. 2006) (Table 2)

Functional gastrointestinal disorders (FGIDs) in pediatric patients include a variable combination of chronic or recurrent, often age-related, symptoms that are not explained by structural or biochemical anomalies. As a result of child development, some functional disorders that occur during childhood accompany normal development (child regurgitation, childhood diarrhea). They may also result from non-adaptive behavioral responses to internal or external stimuli (frequent reasons for functional fecal retention may be painful defecation and / or forced training in the toilet). Diagnosis of (FGIDs) in childhood depends on the child's ability to report symptoms, so some diseases, such as Irritable Bowel Syndrome, are not described in children under a certain age, but this does not rule out its existence in younger children (Rasquin-Weber et al. 1999).

Constipation is a common problem in children and is defined as delayed or obstructed defecation lasting more than two weeks (Xinias and Mavroudi 2015).

Functional constipation is defined by the Rome III (ROME III) classification, with children of at least 4 years of age experiencing some of the following symptoms: 2 or less bowel movements per week; at least one episode of faecal incontinence per week; painful and rigid bowel movements; presence of large amount of fecal mass in the rectum; a large diameter of stools that can interfere with defecation (Afzal et al. 2011).
Table 1. Febrile conditions, cold, flu.

\begin{tabular}{l|l|l}
\hline \multicolumn{1}{c|}{$\begin{array}{c}\text { Conventional } \\
\text { medicines }\end{array}$} & \multicolumn{1}{|c}{$\begin{array}{c}\text { Alternative } \\
\text { medicines }\end{array}$} & \multicolumn{1}{c}{ Bibliography } \\
\hline Antipyretics & $\begin{array}{l}\text { Echinacea } \\
\text { purpurea } \text { (L.) } \\
\text { Moench. }\end{array}$ & $\begin{array}{l}\text { Shah et al. 2007, Bächler et al. } \\
\text { 2018, Ottillinger et al. 2012 }\end{array}$ \\
\hline Analgesics & $\begin{array}{l}\text { Plantago } \\
\text { lanceolata L. }\end{array}$ & Kosenko 2013 \\
\hline NSAIDs & Hedera helix L. & $\begin{array}{l}\text { Kosenko 2013, Safina 2015, } \\
\text { Marzian 2007 }\end{array}$ \\
\hline Antitussive drugs & $\begin{array}{l}\text { Thymus vulgaris } \\
\text { L., Thymus } \\
\text { serpyllium } \text { L. }\end{array}$ & $\begin{array}{l}\text { Safina 2015, Marzian 2007, } \\
\text { Basch et al. 2004 }\end{array}$ \\
\hline Secretolytic drugs & $\begin{array}{l}\text { Cetraria islandica } \\
\text { (L) Ach. }\end{array}$ & $\begin{array}{l}\text { Hecker and Völp 2004, Raal et } \\
\text { al. 2013 }\end{array}$ \\
\hline Antibiotics & $\begin{array}{l}\text { Salix alba L. } \\
\text { Allium sativum } \text { L. }\end{array}$ & Ciuman 2013, Raal et al. 2013 \\
\hline
\end{tabular}

Table 2. Functional dyspepsia.

\begin{tabular}{|c|c|c|}
\hline Conventional drugs & $\begin{array}{l}\text { Alternative drugs/ } \\
\text { Phyto products }\end{array}$ & Bibliography \\
\hline $\begin{array}{l}\text { Antacids; H } 2 \text { - } \\
\text { receptor antagonists; } \\
\text { PP -Proton- } \\
\text { pump inhibitors; } \\
\text { Prokinetics; } \\
\text { Antibiotic }\end{array}$ & $\begin{array}{l}\text { Iberogast; Matricaria } \\
\text { chamomilla L.; } \\
\text { Foeniculum vulgare } \\
\text { Mill.; Mentha } \times \text { piperita } \\
\text { L.; } \text { M. aetheroleum); } \\
\text { Glycyrrhiza glabra } \\
\text { L.; Zyngiber officinale } \\
\text { Roscoe. }\end{array}$ & $\begin{array}{l}\text { Khayyal et al. 2006, } \\
\text { Barden et al. 2009, } \\
\text { Gardiner 2007, } \\
\text { Alexandrovich et } \\
\text { al. 2003, Kooti et al. } \\
\text { 2015, Cohen-Silver } \\
\text { and Ratnapalan 2008, } \\
\text { Klinee et al. 2001, Yeh } \\
\text { and Golianu 2014 }\end{array}$ \\
\hline
\end{tabular}

Medicines commonly used to treat constipation in children include osmotic laxatives, lubricants and stimulants (Philichi 2018).

A study showed that there was no significant difference in success rates in the use of lactulose, anthraquinone (Cassia senna L.) or hydrolyzed guar (Cyamopsis tetragonoloba (L.) Taub.) (Levy et al. 2017) In a review article (Motaharifard et al. 2016) medicinal plants are indicated, for example as: Plantago ovata; Ficus carica; Vitis vinifera; Rosa $\times$ damascena Mill.; Olea europea; Ricinus communis; which are used to prevent and treat constipation in pediatric patients.

\section{Pain control in children}

"Pain is a stressful experience that is considered a global health problem, and children are the most vulnerable and under-served population. Despite the exponential increase in scientific evidence of pediatric pain over the last few decades, there are many barriers to the transfer of knowledge to clinical practice" (Linhares et al. 2012).

"Children of all ages deal with pain. Acute pain can take the form of diagnostic and therapeutic interventions, including venipunctures and immunizations, as well as common childhood misfortunes such as playground injuries. Some children are also subject to chronic or disease-related pain, as in the case of childhood cancers or juvenile arthritis. Many other healthy children may experience chronic functional pain, including chronic daily headaches, abdominal pain, and limb pain" (Evans et al. 2008).

Alternative medical systems are built on complete systems of theory and practice, such as traditional Chinese 
medicine. Biologically based therapies include herbal remedies, as well as vitamins and other dietary supplements (Table 3).

Table 3. Functional abdominal pain.

\begin{tabular}{|c|c|c|}
\hline Conventional drugs & $\begin{array}{l}\text { Alternative drugs/ } \\
\text { Phyto products }\end{array}$ & Bibliography \\
\hline $\begin{array}{l}\text { Spasmolytics; } \\
\text { Analgesics; In functional } \\
\text { dyspepsia }-\mathrm{H}_{2} \text {, blockers }\end{array}$ & $\begin{array}{l}\text { Mentha piperita L. } \\
\text { (M. aetheroleum); } \\
\text { Fumaria officinalis L. } \\
\text { (Fumaria extract) }\end{array}$ & $\begin{array}{l}\text { Asgarshiraziet al. } \\
\text { 2015, Kline et al. } \\
\text { 2001, Montaseri et } \\
\text { al. } 2013\end{array}$ \\
\hline
\end{tabular}

The use of medicinal herbs and herbal medicines is known to humans, but the number of published studies that investigate plant therapies and pain in children is very small (Tsao and Zeltzer 2005).

\section{Conclusion}

Medicinal plants and herbal remedies can be used to treat and prevent mild to moderate illnesses. Discontent with conventional medicine is one of the prerequisites for healthcare professionals - physicians and pharmacists, as well as parents to prefer the use of phytotherapeutic agents. Therefore, it is necessary to provide adequate information on the safety and efficacy of herbal medicines.

\section{References}

Afzal NA, Tighe MP, Thomson MA (2011) Constipation in children. Italian Journal of Pediatrics 37: e28. https://doi.org/10.1186/1824-7288-37-28

Alexandrovich I, Rakovitskaya O, Kolmo E, Sidorova T, Shushunov S (2003) The effect of fennel (Foeniculum vulgare) seed oil emulsion in infantile colic: a randomized, placebo-controlled study. Alternative Therapies in Health and Medicine 9(4): 58-61.

Asgarshirazi M, Shariat M, Dalili H (2015) Comparison of the effects of pH-dependent peppermint oil and synbiotic Lactol (Bacillus coagulans + Fructooligosaccharides) on childhood functional abdominal pain: A randomized Placebo-controlled study. Iranian Red Crescent Medical Journal 17(4): e23844. https://doi.org/10.5812/ircmj.17(4)2015.23844

Bächler A, Feldhaus S, Lang G, Klein P, Suter A, Schoop R (2018) Dose-dependency of Echinacea in the treatment of acute common colds in children 4-12 years. Sociéte Suisse de Pédiatrie, Lausanne.

Barden B, Caspary W, Borner N, Vinsons B, Schneider AR (2009) Clinical effects of STW 5 (Iberogast) are not based on acceleration of gastric emptying in patients with functional dyspepsia and gastroparesis. Neurogastroenterology \& Motility 21(6): 632-e25. https://doi. org/10.1111/j.1365-2982.2008.01249.x

Basch E, Ulbricht C, Hammerness P, Bevins A, Sollars D (2004) Thyme ( Thymus vulgaris L.), Thymol. Journal of Herbal Pharmacotherapy 4(1): 49-67. https://doi.org/10.1080/J157v04n01_07

Borah PK, Gogoi P, Phukan AC, Mahanta J (2006) Traditional medicine in the treatment of gastrointestinal diseases in Upper Assam. Indian Journal of Traditional Knowledge 5(4): 510-512.

Calixto JB (2000) Efficacy, safety, quality control, marketing and regulatory guidelines for herbal medicines (phytotherapeutic agents) Brazilian Journal of medical and Biological research 33(2): 179-189. https://doi.org/10.1590/S0100-879X2000000200004

Ciuman RR (2013) Currently applied clinical naturopathy and Phytotherapy-Keystone for disease prevention and therapy. Medicinal \& Aromatic Plants 2(5). https://doi.org/10.4172/2167-0412.1000137

Cohen MH, Kemper KJ (2005) Complementary therapies in pediatrics: a legal perspective. Pediatrics 115(3): 774-780.

Cohen MH, Kemper KJ, Stevens L, Hashimoto D, Gilmour J (2005) Pediatric use of complementary therapies: ethical and policy choices. Pediatrics 116(4): e568-e575. https://doi.org/10.1542/peds.2005-0496

Cohen-Silver J, Ratnapalan S (2008) Management of infantile colic: A review. Clinical Pediatrics 48(1): 14-17. https://doi. org/10.1177/0009922808323116

Du Y, Wolf I-K, Zhuang W, Bodemann S, Knöss W, Knopf H (2014) Use of herbal medicinal products among children and adolescents in Germany. BMC Complementary and Alternative Medicine 14(1): 1-13. https://doi.org/10.1186/1472-6882-14-218

EU Parliament (2006) Regulation (EC) No 1901/2006 of the European Parliament and of the Council. https://ec.europa.eu/health//sites/ health/files/files/eudralex/vol-1/reg_2006_1901/reg_2006_1901_ bg.pdf [in Bulgarian]

Evans S, Tsao JC, Zeltzer LK (2008) Paediatric Pain Management: Using Complementary and Alternative Medicine. Reviews in Pain 2(1): 14-20. https://doi.org/10.1177/204946370800200104

Gardiner P (2007) Complementary, holistic, and integrative medicine. Pediatrics and Review 28(4): e16. https://doi.org/10.1542/pir.28-4-e16 Gupta RC (2016) Nutraceuticals: Efficacy, Safety and Toxicity. Academic Press, USA.

Hecker M, Völp A (2004) Tolerability of Icelandic moss lozenges in upper respiratory tract diseases - multicentric drug monitoring study with 3,143 children. Research in Complementary and Classical Natural Medicine 11(2): 76-82. https://doi.org/10.1159/000078228

Heikkinen T, Järvinen A (2003) The common cold. Lancet 361(9351): 51-59. https://doi.org/10.1016/S0140-6736(03)12162-9

Jean D, Cyr C (2007) Use of complementary and alternative medicine in a general pediatric clinic. Pediatrics 120(1): e138-e141. https://doi. org/10.1542/peds.2006-3105

Kemper KJ, O’Connor KG (2004) Pediatricians recommendations for complementary and alternative medical (CAM) therapies. Ambulatory Pediatrics 4(6): 482-487. https://doi.org/10.1367/A04-050R.1

Kemper KJ, Vohra S, Walls R (2008) The use of complementary and alternative medicine in pediatrics. Pediatrics 122(6): 1374-1386. https://doi.org/10.1542/peds.2008-2173

Khayyal MT, Seif-El-Nasr M, El-Ghazaly MA, Okpanyi SN, Kelber O, Weiser D (2006) Mechanisms involved in the gastro-protective effect of STW 5(Iberogasts) and its components against ulcers and rebound acidity. Phytomedicine 13: 56-66. https://doi.org/10.1016/j. phymed.2006.03.019 
Kline RM, Kline JJ, Di Palma J, Barbero GJ (2001) Enteric-coated, $\mathrm{pH}$-dependent peppermintoil capsules for the treatment of irritablebowel syndrome in children. The Journal of Pediatrics 138(1): 125-128. https://doi.org/10.1067/mpd.2001.109606

Kooti W, Moradi M, Ali-Akbari S, Sharafi-Ahvazi N, Asadi-Samani M, Ashtary-Larky D (2015) Therapeutic and pharmacological potential of Foeniculum vulgare Mill: a review. Journal of HerbMed Pharmacology 4(1): 1-9.

Kosenko IM (2013) Childhood cough - rational approach to treatment. Current Pediatrics 12(1): 141-148. https://doi.org/10.15690/vsp. v12i1.571

Levy E, Lemmens R, Vandelplas Y, Devreker T (2017) Functional constipation in children: challenges and solutions. Pediatric Health, Medicine and Therapeutics 8: 19-27. https://doi.org/10.2147/PHMT. S110940

Linhares MB, Doca FN, Martinez FE, Carlotti AP, Cassiano RG, Pfeifer L, Funayama CA, Rossi LRG, Finley GA (2012) Pediatric pain: prevalence, assessment, and management in a teaching hospital. Brazilian Journal of Medical and Biological Research 45(12): 1287-1294 https://doi.org/10.1590/S0100-879X2012007500147

Marzian O (2007) Treatment of acute bronchitis in children and adolescents - Non-interventional postmarketing surveillance study confirms the benefit and safety of a syrup made of extracts from thyme and ivy leaves. MMW Fortschritte der Medizin 149(27-28): 69-74.

McCann LJ, Newell SJ (2005) Survey of paediatric complementary and alternative medicine use in health and chronic illness. Archives of Disease in Childhood 91(2): 173-174. https://doi.org/10.1136/ adc. 2004.052514

Menin A (2012) Henri Leclerc and the birth of modern phytotherapy. European Journal of Integrative Medicine 4: 187. https://doi. org/10.1016/j.eujim.2012.07.913

Montaseri S, Pourarian S, Montaseri H (2013) Effects of Fumaria Extract on Colic Pain in 3-16 Weeks Infants. Iranian Journal of Neonatology 4(2): 10-15.

Motaharifard MS, Jafari Z, Paknejad MS, Oveidzadeh L, Karimi M (2016) Prevention and treatment of constipation in children from the perspective of Iranian traditional medicine. Journal of integrative medicine 14(6): 429-435. https://doi.org/10.1016/S20954964(16)60278-9

Ottillinger B, Storr M, Malfertheiner P, Allescher H-D (2012) STW 5 (Iberogast) - a safe and effective standard in the treatment of functional gastrointestinal disorders. Wiener Medizinische Wochenschrift 163(3-4): 65-72. https://doi.org/10.1007/s10354-012-0169-X

Philichi L (2018) Management of childhood functional constipation. Journal of Pediatric Health Care 32(1): 103-111. https://doi. org/10.1016/j.pedhc.2017.08.008
Prussing E, Sobo EJ, Walke E, Dennis K, Kurtin PS (2004) Communicating with pediatricians about complementary/alternative medicine: perspectives from parents of children with Down syndrome. Ambulatory Pediatrics 4(6): 488-494. https://doi.org/10.1367/A03-0368R1.1

Raal A, Volmer D, Soukand R, Hratkevitš S, Kalle R (2013) Complementary treatment of the common cold and fluwith medicinal plants - results from two samples of pharmacy customers in Estonia. PLoS 8(3): e58642. https://doi.org/10.1371/journal.pone.0058642

Rasquin-Weber A, Hyman PE, Cucchiara S, Fleisher DR, Hyams JS, Milla PJ, Staiano A (1999) Childhood functional gastrointestinal disorders. Gut 45(Supplement 2); 60-68. https://doi.org/10.1136/ gut.45.2008.ii60

Safina A (2015) Treatment of young children with recurrent acute respiratory tract infections with a herbal combination of thyme herb and ivy leaf. Zeitschrift Für Phytotherapie 35(06): 262-267. https:// doi.org/10.1055/s-0034-1395797

Salvatore I, Batscheider A, Heinrich J, Wenig C, Bauer CP, Koletzko S, et al. (2012) Utilization and costs of conventional and alternative pharmaceuticalsin children: results from the German GINIplus and LISAplus birthcohort studies. Pharmacoepidemiology and Drug Safety 21(10): 1102-1111. https://doi.org/10.1002/pds.3323

Shah SA, Sander S, White CM, Rinaldi M, Coleman CI (2007) Evaluation of echinacea for the prevention and treatment of the common cold: a meta-analysis. The Lancet Infectious Diseases 7(7): 473-480. https://doi.org/10.1016/S1473-3099(07)70160-3

Troullos E, Baird L, Jayawardena S (2014) Common cold symptoms in children: results of an internet-based surveillance program. Journal of Medical Internet Research 16(6): e144. https://doi.org/10.2196/ jmir.2868

Tsao JC, Zeltzer LK (2005) Complementary and alternative medicine approaches for pediatric pain: a review of the state-of-the-science. Evidence-Based Complementary and Alternative Medicine 2(2): 149-159. https://doi.org/10.1093/ecam/neh092

Weiss RF, Fintelmann V (2000) Herbal Medicine (2 ${ }^{\text {nd }}$ edn.). Thieme Medical Publishers, Stuttgart.

Woolf AD (2013) Herbal remedies and children: Do they work? Are they harmful? Pediatrics 112(1): 240-246.

Xinias I, Mavroudi A (2015) Constipation in childhood - An update on evaluation and management. Hippokratia 19(1): 11-19.

Yeh AM, Golianu B (2014) Integrative treatment of Reflux and Functional Dyspepsia in Children. Childrern (Basel) 1(2): 119-133.

Zuzak TJ, Bonková J, Careddu D, Garami M, Hadjipanayis A, Jazbec J, et al. (2013) Use of complementary and alternative medicine by children in Europe: Published data and expert perspectives. Complementary Therapies in Medicine 21S: 34-37. https://doi.org/10.1016/j. ctim.2012.01.001 